\title{
Selenium Increases Sulfur Uptake and Regulates Glucosinolate Metabolism in Rapid-cycling Brassica oleracea
}

\author{
Heather D. Toler, Craig S. Charron, and Carl E. Sams ${ }^{1}$ \\ The University of Tennessee, Plant Sciences Department, Room 252 Plant Science Building, 2431 \\ Joe Johnson Drive, Knoxville, TN 37996 \\ William R. Randle \\ Department of Horticulture, The University of Georgia, Athens, GA 30602
}

\begin{abstract}
AdDITIONAL INDEX wORDS. Brassicaceae, selenium nutrition, anticarcinogenic, isothiocyanates
Abstract. Glucosinolates are sulfur-containing secondary plant metabolites commonly found in the family Brassicaceae. The presence of selenium in soils increases the uptake of sulfur and inhibits the production of glucosinolates in brassicaceous plants. This study was undertaken to determine the extent of selenium's impact on sulfur uptake and glucosinolate production in Brassica oleracea $\mathbf{L}$. Rapid-cycling B. oleracea plants were grown hydroponically in half-strength Hoagland's nutrient solution with selenium treatments delivered as sodium selenate concentrations of $0.0,0.5,0.75,1.0$, and $1.5 \mathrm{mg} \cdot \mathrm{L}^{-1}$. Elevated sulfur treatments of $37 \mathrm{mg} \cdot \mathrm{L}^{-1} \mathrm{sulfate}$ and $37 \mathrm{mg} \cdot \mathrm{L}^{-1}$ sulfate $/ 0.75 \mathrm{mg} \cdot \mathrm{L}^{-1}$ selenate were incorporated to compare with selenium treatments. Plants were harvested and freeze-dried 1 day before anthesis. Selenium and sulfur content of plant tissue was determined by flame atomic absorption spectrophotometry and a carbon-nitrogen-sulfur analyzer. Glucosinolate content of leaf tissue was determined by high-performance liquid chromatography. Selenium and sulfur uptake in plants positively correlated with selenium concentration in the nutrient solution. The sulfur concentration of plants exposed to selenium equaled or exceeded the sulfur concentration of plants exposed to elevated sulfur. Despite higher sulfur concentrations, there occurred a statistically significant decrease in production of five of the seven glucosinolates analyzed in seleniumenriched plants. Plants that underwent elevated sulfur treatments had higher glucosinolate production than seleniumtreated plants. These results suggest that selenium either upregulates or prevents the downregulation of sulfur uptake in B. oleracea. In addition, the presence of selenium within the plant appears to have a negative impact on the production of certain glucosinolates despite adequate availability of sulfur.
\end{abstract}

Plants in the family Brassicaceae play integral roles in the diets of the world's population. Brassica oleracea, for example, includes the following staple food cultivars: cabbage, broccoli, cauliflower, kale, kohlrabi, and brussels sprouts. Brassicaceous plants are also known for their production of the S-containing secondary plant metabolites, glucosinolates.

Glucosinolate concentrations in plants can significantly alter an animal's health. High-glucosinolate diets initiate such undesirable effects as enlargement of the thyroid gland, decreased organ weight, and obstruction of nitrogen nutrition pathways. Such diets are typically associated with grazing animals consuming large quantities of glucosinolate-containing forage. (Brown and Morra, 1997; Fahey et al., 2001; Louda and Mole, 1991; Rosa et al., 1997). In contrast to the negative health effects associated with high-glucosinolate diets, moderated intake of glucosinolate-containing plants (as seen in humans) is associated with a decreased risk of cancer (Gross et al., 2000; Hecht, 2000; Zhang and Talalay, 1994). When consumed, glucosinolates are broken down into their hydrolysis productsisothiocyanates - which in turn stimulate the activities of the anticarcinogenic phase II human enzymes.

The production of glucosinolates in brassicaceous plants is influenced by a number of factors, one of which is nutrition. A plant nutrient of specific interest is Se. Selenium is similar to $\mathrm{S}$ in both size and chemistry, and thus often substitutes for $\mathrm{S}$ in

Received for publication 18 Aug. 2006. Accepted for publication 12 Oct. 2006. ${ }^{1}$ Corresponding author. E-mail: carlsams@utk.edu. physiological and metabolic processes (Anderson and Scarf, 1983). Charron et al. (2001), for example, found that total glucosinolate production in rapid-cycling $B$. oleracea decreased when grown in the presence of sodium selenate. Furthermore, sulfate uptake has been shown to increase in $B$. oleracea with increasing selenate concentrations in nutrient solutions ranging from 0 to $9 \mathrm{mg} \cdot \mathrm{L}^{-1}$ (Charron et al., 2001; Kopsell and Randle, 1999; Toler and Sams, 2001). Glucosinolate production in the aforementioned studies was not investigated at the narrow range of Se concentrations suitable for human consumption.

Selenium is essential to animal nutrition [humans have a daily requirement of $50-70 \mu \mathrm{g} \cdot \mathrm{d}^{-1}$ (U.S. Department of Agriculture, 2003)] as a component of the enzymes glutathione peroxidase, selenoprotein $\mathrm{P}$, and tetraiodothyronine $5^{\prime}$-deiodinase. In addition, studies have shown a dietary Se supplement of 100 to 200 $\mu \mathrm{g} \cdot \mathrm{d}^{-1}$ results in a decreased incidence of such cancers as lung and prostate (Clark et al., 1996; Ip and Ganther, 1992; Ip et al., 1991; Lauchli, 1993). However, daily intakes in humans exceeding $700 \mu \mathrm{g} \cdot \mathrm{d}^{-1}$ will result in toxicity (Levander 1982).

Given the importance of Se to mammalian nutrition, the beneficial anticarcinogen-inducing properties of small amounts of glucosinolate breakdown products, and the negative health effects that both glucosinolate breakdown products and Se can induce in excessive quantities, it is essential to elucidate further the Se-S relationship with regard to glucosinolate production in the widely consumed B. oleracea. The objectives of this study were therefore 1) to determine the concentrations at which 
sodium selenate can be present in media of hydroponically grown rapid-cycling $B$. oleracea and still yield plants with Se concentrations suitable for maximum human health benefit, 2) to determine the impact of Se on the production of glucosinolates in $B$. oleracea with a sodium selenate treatment range yielding Se concentrations in plant tissue most suitable for human health, and 3) to determine the impact of elevated sulfate in plant growing media on the uptake of $\mathrm{S}$ and production of glucosinolates by rapid-cycling $B$. oleracea, relative to the impact of Se on $\mathrm{S}$ uptake and glucosinolate production.

\section{Materials and Methods}

EXPERIMENTAL SETUP. Rapid-cycling B. oleracea plants were grown hydroponically in half-strength, modified, Hoagland's nutrient solution under 24-h controlled metal halide lamps [photosynthetically active radiation $(P A R)$ values ranging from 300-450 $\left.\mu \mathrm{mol} \cdot \mathrm{m}^{-2} \cdot \mathrm{s}^{-1}\right]$ and temperature $\left(30.3^{\circ} \mathrm{C} \pm 1.1^{\circ} \mathrm{C}\right)$. The rapid-cycling $B$. oleracea seeds were obtained from the University of Wisconsin, Department of Plant Pathology and were sown in Oasis (Smithers-Oasis, Kent, Ohio) growing medium cubes resting in the hydroponic reservoirs.

Plant reservoirs were placed under one of three sets of highintensity metal halide lamps. Four circular holes were cut in a staggered arrangement in the lid of each reservoir. Oasis cubes were cut to match the circular lid holes such that each cube could slide through the hole with the uncut section of the cube resting on the lid. The length of the cube hanging through the bottom of the lid was sufficient to come in contact with $1.8 \mathrm{~L}$ nutrient solution after it was added to the reservoir base and the lid was settled into place. Thus, the oasis material acted as a wick, supplying moisture to germinating seeds and nutrients to young roots. At the beginning of the experiment, two seeds were sown in each Oasis cube, covered with a tiny crumble of spare Oasis cube material, and lightly watered with $4 \mathrm{~mL}$ distilled deionized $\mathrm{H}_{2} \mathrm{O}$. After germination, one of the plants was removed to establish initial uniformity in size among all plants in the experiment.

The height of each lamp set above the reservoirs was adjusted to provide the highest $P A R$ value while maintaining as much uniformity in light intensity at all reservoirs as possible. After lamp height from each reservoir was established, the distance from lamps to plant was maintained as the plants grew by raising the lamps. Using a light intensity meter, the PAR value at each reservoir's position was recorded.

One week after germination and the appearance of the first true leaves, treatments were initiated. There were five replications of each treatment, with an individual reservoir representing an experimental unit. The treatments consisted of the control (half-strength Hoagland's nutrient solution, containing no Se), four Se treatments $\left(0.5,0.75,1.0\right.$, and $1.5 \mathrm{mg} \cdot \mathrm{L}^{-1}$ $\left.\mathrm{Na}_{2} \mathrm{SeO}_{4}\right)$, an elevated $\mathrm{S}$ treatment $\left(37 \mathrm{mg} \cdot \mathrm{L}^{-1} \mathrm{SO}_{4}{ }^{2-}\right.$ delivered on top of the preexisting $96 \mathrm{mg} \cdot \mathrm{L}^{-1} \mathrm{SO}_{4}{ }^{2-}$ already present in the half-strength Hoagland's solution), and an Se/elevated $\mathrm{S}$ treatment $\left(0.75 \mathrm{mg} \cdot \mathrm{L}^{-1} \mathrm{Na}_{2} \mathrm{SeO}_{4} / 37 \mathrm{mg} \cdot \mathrm{L}^{-1} \mathrm{SO}_{4}{ }^{2-}\right)$.

Twenty-nine to $30 \mathrm{~d}$ after seeds were planted, just before anthesis, all plants were harvested. At the time of harvest, plant height and stem width measurements were taken. Leaves, stems, and roots from each reservoir were bagged and immediately frozen in $\mathrm{a}-30{ }^{\circ} \mathrm{C}$ freezer. When frozen, all tissue was lyophilized to remove water content for dry biomass determination and to prevent glucosinolate degradation.
Glucosinolate anAlysis of LEAF Tissue. Glucosinolates in lyophilized leaf tissue were extracted and analyzed by highperformance liquid chromatography on an HP1050 Series pump with variable Wavelength 1050 Series Detector (Hewlett Packard, Palo Alto, Calif.) via a method outlined by Charron et al. (2001). Identification of desulfonated glucosinolate peaks was determined by running the desulfonated glucosinolate standards glucoiberin, progoitrin, epiprogoitrin, sinigrin, sinalbin, gluconapin, glucobarbarin, glucotropaeolin, glucobrassicin, 4-methoxyglucobrassicin, gluconasturtiin, glucoraphanin, and neoglucobrassicin on a liquid chromatograph using the previous method and then comparing retention times of standards with samples. These desulfoglucosinolates have previously been verified by gas chromatography mass spectrophotometry by Christensen et al. (1982). Analysis was performed on a Chemstation software module (version 6.03; Hewlett Packard).

Nutrient anAlysis OF LEAF Tissue. Selenium content of leaf tissue was determined at the University of Georgia, Department of Horticulture via a method outlined by Kopsell and Randle (1997a). Total S content of leaf tissue was determined by combusting $0.2 \mathrm{~g}$ leaf tissue on a LECO CNS-2000 analyzer (Leco Corp., St. Joseph, Mich.) at the University of Tennessee, Department of Plant Sciences. In addition to Se and total S content, sulfate concentrations of leaf tissue were determined at the University of Georgia, Department of Horticulture via methods outlined by Randle et al. (2002).

EXPerimental Design and STATistical anAlysis. Because there were temperature differences between the three sets of lamps, and temperature has been reported to influence the production of glucosinolates in B. oleracea (Charron et al., 2005), the experiment was blocked by temperature. The space under each of the three lamp sets represented one block, for a total of three blocks. Because an equal number of replications of each treatment could not be fit under each lamp set, the experimental design was an unbalanced, incomplete block design.

Light intensity can cause variations in plant growth physiology. The $P A R$ value under each lamp set varied between 300 to $450 \mu \mathrm{mol} \cdot \mathrm{m}^{-2} \cdot \mathrm{s}^{-1}$ from one reservoir position to the next. The exact $P A R$ value at each reservoir's position was recorded and a covariate for this factor was included as part of the experimental design. The full experimental design, therefore, was an unbalanced, incomplete block design with a covariate on light intensity. Statistical analysis of data was performed using SAS (version 9.00 for Windows; SAS Institute, Cary, N.C.).

\section{Results and Discussion}

General Plant health. Neither stem width nor tissue biomass was statistically significantly different among treatments (Table 1). Plants exposed to $1.5 \mathrm{mg} \cdot \mathrm{L}^{-1}$ sodium selenate exhibited a $38 \%$ decrease in height when compared with control plants, however. This is not surprising. Although rapid-cycling $B$. oleracea are Se hyperaccumulators, Se is not an essential macronutrient or micronutrient to plants, and can therefore act as a stress factor and reduce height. Plants exposed to the 37 $\mathrm{mg} \cdot \mathrm{L}^{-1}$ sulfate treatment and the $37 \mathrm{mg} \cdot \mathrm{L}^{-1}$ sulfate $/ 0.75 \mathrm{mg} \cdot \mathrm{L}^{-1}$ selenate treatment were statistically taller than plants in all Se treatments (Table 1).

Glucosinolates. The glucosinolates extracted from the rapid-cycling $B$. oleracea plants and identified by high-performance liquid chromatography as desulfoglucosinolates were 
Table 1. The effects of selenate and elevated sulfate ${ }^{z, y}$ on stem width, plant height, fresh tissue biomass, and dry tissue biomass in rapid-cycling Brassica oleracea.

\begin{tabular}{|c|c|c|c|c|c|c|c|c|}
\hline \multirow[b]{2}{*}{ Treatments $\left(\mathrm{mg} \cdot \mathrm{L}^{-1}\right)$} & \multirow[b]{2}{*}{ Stem width (mm) } & \multirow[b]{2}{*}{ Plant ht. (cm) } & \multicolumn{3}{|c|}{ Fresh wt $(\mathrm{g})$} & \multicolumn{3}{|c|}{ Dry wt $(\mathrm{g})$} \\
\hline & & & Leaves & Stems & Roots & Leaves & Stems & Roots \\
\hline Control & $5.3 \mathrm{a}$ & $17.8 \mathrm{a}$ & $23.8 \mathrm{a}$ & $6.06 \mathrm{a}$ & $20.4 \mathrm{ab}$ & $12.31 \mathrm{a}$ & $0.53 \mathrm{a}$ & $1.13 \mathrm{a}$ \\
\hline $0.5 \mathrm{SeO}_{4}^{2-}$ & $4.9 \mathrm{ab}$ & $12.6 \mathrm{~b}$ & $26.2 \mathrm{a}$ & $4.78 \mathrm{a}$ & $20.8 \mathrm{ab}$ & $2.32 \mathrm{a}$ & $0.35 \mathrm{ab}$ & $1.08 \mathrm{a}$ \\
\hline $1.0 \mathrm{SeO}_{4}^{2-}$ & $4.7 \mathrm{ab}$ & $14.1 \mathrm{ab}$ & $23.5 \mathrm{a}$ & $5.01 \mathrm{a}$ & $22.9 \mathrm{ab}$ & $2.31 \mathrm{a}$ & $0.40 \mathrm{ab}$ & $1.22 \mathrm{a}$ \\
\hline $1.5 \mathrm{SeO}_{4}^{2-}$ & $4.5 \mathrm{~b}$ & $11.1 \mathrm{~b}$ & $23.8 \mathrm{a}$ & $4.07 \mathrm{a}$ & $22.4 \mathrm{ab}$ & $2.15 \mathrm{a}$ & $0.29 \mathrm{~b}$ & $1.11 \mathrm{a}$ \\
\hline $37 \mathrm{SO}_{4}^{2-}$ & $5.1 \mathrm{ab}$ & $18.1 \mathrm{a}$ & $24.5 \mathrm{a}$ & $5.80 \mathrm{a}$ & $17.7 \mathrm{ab}$ & $2.41 \mathrm{a}$ & $0.51 \mathrm{a}$ & $1.03 \mathrm{a}$ \\
\hline $\mathrm{SE}^{\mathrm{x}}$ & 0.30 & 2.14 & 4.09 & 1.13 & 5.41 & 0.42 & 0.13 & 0.25 \\
\hline$P$ value & 0.21 & $<0.05$ & 0.77 & 0.37 & 0.39 & 0.97 & 0.13 & 0.76 \\
\hline
\end{tabular}

Plants were exposed to selenate concentrations ranging from 0 to $1.5 \mathrm{mg} \cdot \mathrm{L}^{-1}$, or an elevated sulfate of $37 \mathrm{mg} \cdot \mathrm{L}^{-1} \mathrm{more}$ than the $96 \mathrm{mg} \cdot \mathrm{L}^{-1}$ sulfate concentration preexisting in the nutrient solution.

${ }^{z}$ Elevated sulfate concentration is equal to $37 \mathrm{mg} \cdot \mathrm{L}^{-1}+96 \mathrm{mg} \cdot \mathrm{L}^{-1}=133 \mathrm{mg} \cdot \mathrm{L}^{-1}$.

'Letters represent mean separations by Fisher's LSD test.

${ }^{\mathrm{x}} \mathrm{SE}$ of the least square mean.

glucoiberin, progoitrin, glucoraphanin, sinigrin, gluconapin, glucobrassicin, and neoglucobrassicin. All glucosinolates identified in rapid-cycling $B$. oleracea were identified in the $B$. oleracea plants: white cabbage, red cabbage, savoy cabbage, brussels sprouts, kale, cauliflower, and kohlrabi (Ciska et al., 2000). Low/trace concentrations of 4-methoxyglucobrassicin, 4-hydroxyglucobrassicin, and gluconasturtiin were also reported in these plants and broccoli, but were not accurately detectable in the rapid-cycling plants (Ciska et al., 2000; Kushad et al., 1999).

Overall, total glucosinolate concentrations in rapid-cycling $B$. oleracea were higher in the elevated sulfate treatment. This is consistent with increases in total glucosinolate concentrations observed in Brassica napus L. and Brassica rapa L. grown under increasingly elevated $\mathrm{S}$ regimes (Mailer, 1989). This is the first report on the influence of elevated $\mathrm{S}$ on glucosinolate production in rapid-cycling $B$. oleracea. The dearth of research on elevated $\mathrm{S}$ influencing glucosinolate production in B. oleracea is most likely the result of most cultivars of this species being consumed in relatively small quantities by humans. $B$. napus, on the other hand, is consumed in larger quantities as high-protein meal by livestock. The negative health impacts associated with the consumption of large quantities of glucosinolates have thus spurred $\mathrm{S}$ research with $B$. napus, whereas $\mathrm{S}$ influences on $B$. oleracea remain largely unexamined.

Individually, the production of glucoiberin and glucoraphanin decreased with increasing Se concentrations in nutrient solutions $(P<0.01)$. Plants that underwent the $1.5 \mathrm{mg} \cdot \mathrm{L}^{-1}$ selenate treatment exhibited a $58 \%$ and $68 \%$ reduction in the production of glucoiberin and glucoraphanin respectively when compared with plants in the control treatment. Furthermore, plants exposed to elevated sulfate levels in nutrient solution exhibited a significant increase in both glucoiberin and glucoraphanin production, with concentrations $11 \%$ and $16 \%$ higher respectively than the control. Plants in the $0.75 \mathrm{mg} \cdot \mathrm{L}^{-1}$ selenate/ $37 \mathrm{mg} \cdot \mathrm{L}^{-1}$ elevated sulfate treatment had glucoiberin and glucoraphanin production equal to plants in the $0.5 \mathrm{mg} \cdot \mathrm{L}^{-1}$ selenate treatment (Table 2).

The R-groups of glucoiberin and glucoraphanin are both derived from methionine. Unlike other glucosinolates investigated with R-groups that are derived from methionine, glucoiberin and glucoraphanin retain the $\mathrm{S}$ atom from methionine. In addition, recent experiments with the genetic control of the final side-chain modification step in the biosynthesis of both glucoiberin and glucoraphanin have revealed that both are controlled by the same genetic alleles at the Gsl-oxid locus (defined as a specific location on a chromosome) of the plant's chromosome (Halkier and Du, 1997; Kliebenstein et al., 2001).

Progoitrin production was not significantly affected by any of the treatments $(P=0.25$; data not shown). Like glucoiberin and glucoraphanin, the amino acid precursor for progoitrin is methionine. However, unlike the other glucosinolates identified in rapid-cycling $B$. oleracea in this experiment, progoitrin does not retain the $\mathrm{S}$ from methionine, and its final side-chain modification is controlled by alleles at the Gsl-oh locus of the plant's chromosome (Halkier and Du, 1997; Kliebenstein et al., 2001).

Like glucoiberin and glucoraphanin, the production of sinigrin $(P<0.01)$ and gluconapin $(P<0.05)$ was significantly hindered by the presence of Se in nutrient solutions. Unlike glucoiberin and glucoraphanin, however, the decrease in sinigrin and gluconapin concentrations was a sharp drop in production at any Se exposure $(\approx 34 \%$ to $38 \%$ less than control plants) rather than a gradual decrease with increasing treatment concentrations. There were no notable differences in glucosinolate concentrations among the Se treatments themselves. The $37 \mathrm{mg} \cdot \mathrm{L}^{-1}$ sulfate treatment yielded higher sinigrin and gluconapin concentrations than control plants, with concentrations being $4 \%$ and $16 \%$ higher respectively. Plants in the 0.75 $\mathrm{mg} \cdot \mathrm{L}^{-1}$ selenate $/ 37 \mathrm{mg} \cdot \mathrm{L}^{-1}$ sulfate treatment had sinigrin concentrations falling between controls and Se treatment plants (Table 2). Interestingly, gluconapin concentrations in plants in the $0.75 \mathrm{mg} \cdot \mathrm{L}^{-1}$ selenate $/ 37 \mathrm{mg} \cdot \mathrm{L}^{-1}$ sulfate treatment were significantly higher than any other treatment, including $9.5 \%$ higher than the $37 \mathrm{mg} \cdot \mathrm{L}^{-1}$ sulfate treatment.

Like glucoiberin, glucoraphanin, and progoitrin, the R-groups of sinigrin and gluconapin are derived from methionine. However, sinigrin and gluconapin do not retain the $\mathrm{S}$ from methionine within their molecular structures. Unlike all three aforementioned glucosinolates, final side-chain modification of sinigrin and gluconapin is controlled by alleles at the Gsl-alk locus of the plant's chromosome (Halkier and Du, 1997; Kliebenstein et al., 2001).

Glucobrassicin concentrations in leaf tissue were decreased by the presence of Se in nutrient solutions $(P<0.05)$. Plants in 
Table 2. The effects of selenate and elevated sulfate ${ }^{z, y}$ on the concentrations of glucoiberin, glucoraphanin, sinigrin, gluconapin, glucobrassicin, and neoglucobrassicin in rapid-cycling Brassica oleracea.

\begin{tabular}{lcclccc}
\hline Treatments $\left(\mathrm{mg} \cdot \mathrm{L}^{-1}\right)$ & Glucoiberin & Glucoraphanin & Sinigrin & Gluconapin & Glucobrassicin & Neoglucobrassicin \\
\hline Control & $702 \mathrm{a}$ & $694 \mathrm{a}$ & $3385 \mathrm{ab}$ & $3474 \mathrm{abc}$ & $2229 \mathrm{ab}$ & $655 \mathrm{~b}$ \\
$0.5 \mathrm{SeO}_{4}{ }^{2-}$ & $489 \mathrm{~b}$ & $415 \mathrm{bc}$ & $2538 \mathrm{c}$ & $2414 \mathrm{c}$ & $2025 \mathrm{abc}$ & $772 \mathrm{ab}$ \\
$0.75 \mathrm{SeO}_{4}{ }^{2-}$ & $360 \mathrm{bc}$ & $242 \mathrm{~cd}$ & $2310 \mathrm{c}$ & $3031 \mathrm{bc}$ & $1951 \mathrm{abc}$ & $715 \mathrm{~b}$ \\
$1.0 \mathrm{SeO}_{4}^{2-}$ & $362 \mathrm{bc}$ & $247 \mathrm{~cd}$ & $2545 \mathrm{c}$ & $2777 \mathrm{c}$ & $1241 \mathrm{bc}$ & $702 \mathrm{~b}$ \\
$1.5 \mathrm{SeO}_{4}{ }^{2-}$ & $298 \mathrm{c}$ & $222 \mathrm{~d}$ & $2453 \mathrm{c}$ & $2297 \mathrm{c}$ & $1490 \mathrm{bc}$ & $2701 \mathrm{a}$ \\
$37 \mathrm{SO}_{4}{ }^{2-}$ & $780 \mathrm{a}$ & $817 \mathrm{a}$ & $3516 \mathrm{a}$ & $4111 \mathrm{ab}$ & $1162 \mathrm{c}$ & 522 \\
$0.75 \mathrm{SeO}_{4}{ }^{2-} / 37 \mathrm{SO}_{4}{ }^{2-}$ & $496 \mathrm{~b}$ & $459 \mathrm{~b}$ & $2765 \mathrm{bc}$ & $4539 \mathrm{a}$ & $496 \mathrm{a}$ \\
$\mathrm{SE}^{\mathrm{x}}$ & 90 & 69 & 402 & 451 & $<0.05$ & 234 \\
$P$ value & $<0.05$ & $<0.05$ & $<0.05$ & $<0.05$ & 0.17
\end{tabular}

All concentrations are in micromoles per gram dry weight in leaf tissue of hydroponically grown rapid-cycling B. oleracea. Plants were exposed to selenate concentrations ranging from 0 to $1.5 \mathrm{mg} \cdot \mathrm{L}^{-1}$, or an elevated sulfate of $37 \mathrm{mg} \cdot \mathrm{L}^{-1}$ more than the $96 \mathrm{mg} \cdot \mathrm{L}^{-1}$ sulfate concentration preexisting in the nutrient solution.

${ }^{\mathrm{z}}$ Elevated sulfate concentration is equal to $37 \mathrm{mg} \cdot \mathrm{L}^{-1}+96 \mathrm{mg} \cdot \mathrm{L}^{-1}=133 \mathrm{mg} \cdot \mathrm{L}^{-1}$.

${ }^{y}$ Letters represent mean separations by Fisher's LSD test.

${ }^{\mathrm{x}} \mathrm{SE}$ of the least square mean.

the $1.5 \mathrm{mg} \cdot \mathrm{L}^{-1}$ selenate treatment had a $34 \%$ reduction in glucobrassicin production when compared with the control. Plants in the $37 \mathrm{mg} \cdot \mathrm{L}^{-1}$ elevated sulfate treatment exhibited a $17.5 \%$ increase in glucobrassicin production when compared with the control. Plants in the $0.75 \mathrm{mg} \cdot \mathrm{L}^{-1}$ selenate $/ 37 \mathrm{mg} \cdot \mathrm{L}^{-1}$ elevated sulfate treatment had the lowest concentrations of glucobrassicin at $22 \%$ less than that of the $1.5 \mathrm{mg} \cdot \mathrm{L}^{-1}$ selenate treatment (Table 2).

Unlike glucobrassicin, neoglucobrassicin concentrations were not significantly affected by any of the treatments $(P=$ $0.17)$. Although statistical nonsignificance precludes the drawing of any conclusions about possible trends in neoglucobrassicin production, the concentrations of this glucosinolate appear to behave similarly to that of glucobrassicin. Further experimentation with greater treatment replication might eliminate the experimental variation causing the statistical nonsignificance (Table 2).

Because data on the genetic control of the biosynthesis of individual glucosinolates has only begun to be elucidated by researchers in recent years, information on the alleles controlling side-chain modification in glucobrassicin and neoglucobrassicin is currently unavailable. However, it is known that the amino acid precursor for the R-group of these two glucosinolates is tryptophan rather than methionine. This difference in R-group amino acid precursor may help to explain the differences in production of glucobrassicin and neoglucobrassicin, relative to the other glucosinolates analyzed.

The production of the individual glucosinolates in this study appears to follow patterns based on the R-group. The concentrations of glucoiberin and glucoraphanin, for example, decreased with increasing Se concentrations in nutrient solution. This could be the result of their R-group retention of the $S$ from their amino acid precursor and regulation by the same alleles at the Gsl-oxid locus. Sinigrin and gluconapin, both belonging to the straight-chain R-group and controlled by alleles at the Gsl-alk locus, behaved similarly in that the inhibition in their production did not increase with increasing Se concentrations in nutrient solution. The production of glucobrassicin and neoglucobrassicin, both belonging to the indole R-group with tryptophan as an amino acid precursor, showed a greater increase in concentrations at the elevated $\mathrm{S}$ treatment when compared with other glucosinolates. Progoitrin, the production of which is controlled by alleles at the Gsl-oh locus, also differed from other glucosinolates analyzed in that it was unaffected by the treatments used.

The observed patterns of glucosinolate production and their association to specific regions of the plant chromosome responsible for the modification of their R-group side chains is significant. It suggests that the influence Se exerts on glucosinolate production in $B$. oleracea may extend to the genetic level. Hence, presence of Se in a plant may not only affect glucosinolate production at the site of glucosinolate biosynthesis, but it may affect the genetic control of glucosinolate biosynthesis as well.

NUTRIENT ANALYSIS OF LEAF TISSUE. Selenium content of leaf tissue increased with increasing Se concentrations in nutrient solution. Means ranged from 0 to $373 \mu \mathrm{g} \cdot \mathrm{g}^{-1}$ in the 0 to $1.5 \mathrm{mg} \cdot \mathrm{L}^{-1}$ selenate treatments respectively. Selenium concentrations $(200$ $\mu \mathrm{g} \cdot \mathrm{g}^{-1}$ ), associated with a decreased risk of cancer in humans, occurred at the Se treatments of $0.5 \mathrm{mg} \cdot \mathrm{L}^{-1}$ and $0.75 \mathrm{mg} \cdot \mathrm{L}^{-1}$ (with concentrations of $178 \mu \mathrm{g} \cdot \mathrm{g}^{-1}$ and $218 \mu \mathrm{g} \cdot \mathrm{g}^{-1}$ respectively). Plants

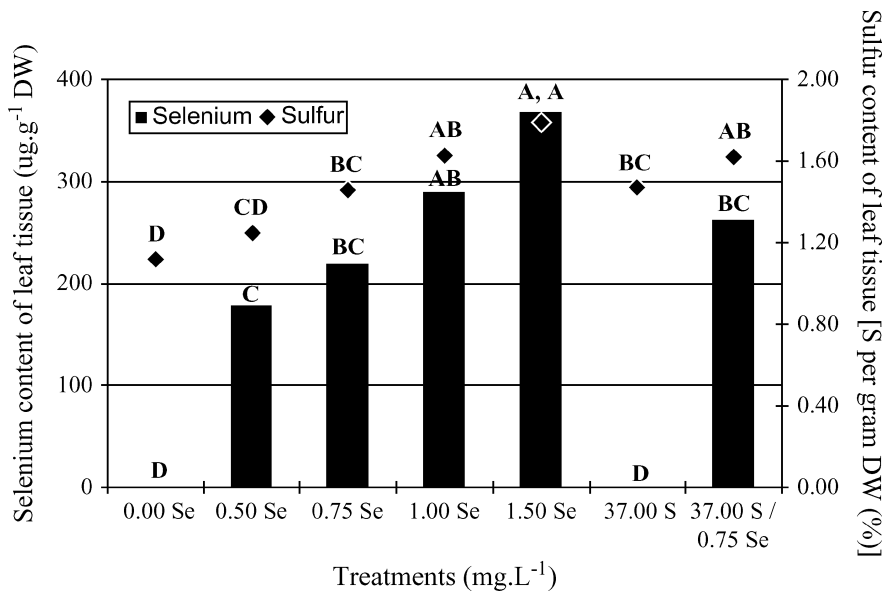

Fig. 1. Selenium (micrograms per gram dry weight) and sulfur (percent per gram dry weight) concentrations in leaf tissue of hydroponically grown rapidcycling Brassica oleracea at 30 to $31 \mathrm{~d}$. Plants were exposed to Se concentrations ranging from 0 to $1.5 \mathrm{mg} \cdot \mathrm{L}^{-1}$, or an elevated $\mathrm{S}$ of $37 \mathrm{mg} \cdot \mathrm{L}^{-1}$ more than the $96 \mathrm{mg} \cdot \mathrm{L}^{-1}$ sulfate concentration preexisting in the nutrient solution $(P<0.01)$. Letters represent significant mean separations by Fisher's LSD test. 
exposed to both $0.75 \mathrm{mg} \cdot \mathrm{L}^{-1}$ selenate, in addition to elevated sulfate concentrations of $37 \mathrm{mg} \cdot \mathrm{L}^{-1}$, had a mean Se concentration of $245 \mu \mathrm{g} \cdot \mathrm{g}^{-1}$ in the leaf tissue $(P<0.01$; Fig. 1$)$.

Broccoli and cabbage grown in soils with a base Se concentration of $0.1 \mu \mathrm{g} \cdot \mathrm{g}^{-1}$ and fertilized with $3 \mathrm{mg} \cdot \mathrm{L}^{-1} \mathrm{~K}_{2} \mathrm{SeO}_{4}$ were shown to have Se concentrations of $\approx 150 \mu \mathrm{g} \cdot \mathrm{g}^{-1}$ dry weight. Carrots (Daucus carota L.) and lettuce (Lactuca sativa L.) grown under the same conditions had Se concentrations of 30 to 50 $\mu \mathrm{g} \cdot \mathrm{g}^{-1}$ dry weight (Hamilton and Beath, 1964). The fact that the broccoli and cabbage were grown in soil may explain the lower Se concentrations in their tissue when compared with hydroponically grown rapid-cycling $B$. oleracea plants exposed to lower selenate concentrations. Some of the selenate molecules administered would adhere to soil particles, making them less available to the plants for uptake. Furthermore, the increase of Se concentrations in soil-grown $B$. oleracea cultivars by application of selenate fertilizer suggests that it may be readily possible to produce niche crops of Se-enriched B. oleracea with Se concentrations ranging from 150 to $200 \mu \mathrm{g} \cdot \mathrm{g}^{-1}$.

Sulfur content is expressed in percent $\mathrm{S}$ per gram dry weight. The percentage of $\mathrm{S}$ content in leaf tissue was significantly affected by $\mathrm{Se}$ and $\mathrm{S}$ treatments $(P<0.01)$. Sulfur concentrations in leaf tissue increased from $1.2 \%$ to $1.8 \%$ as Se concentrations in nutrient solution increased. The percentage of $\mathrm{S}$ content of plants exposed to the elevated $\mathrm{S}$ treatment was similar to that of plants exposed to the $0.75 \mathrm{mg} \cdot \mathrm{L}^{-1}$ selenate treatment. Plants exposed to the $0.75 \mathrm{mg} \cdot \mathrm{L}^{-1}$ selenate $/ 37 \mathrm{mg} \cdot \mathrm{L}^{-1}$ sulfate treatment had a $\mathrm{S}$ content in their leaf tissue equal to that of plants exposed to the $1.0 \mathrm{mg} \cdot \mathrm{L}^{-1}$ selenate treatment (Fig. 1).

Sulfate content of leaf tissue (in milligrams per gram) reflected the trends of percent $\mathrm{S}$ content. Selenium and $\mathrm{S}$ treatments significantly influenced the concentration of sulfate in rapid-cycling $B$. oleracea plants $(P<0.01)$. Increasing Se concentration in nutrient solutions resulted in an increase in sulfate concentrations in leaf tissue, ranging from $46.4 \mathrm{mg} \cdot \mathrm{g}^{-1}$ in the control treatment to $65.9 \mathrm{mg} \cdot \mathrm{g}^{-1}$ in the $1.5 \mathrm{mg} \cdot \mathrm{L}^{-1}$ selenate treatment. Plants exposed to elevated sulfate in nutrient solutions had sulfate concentrations in their leaf tissue equal to that of plants in the $0.5 \mathrm{mg} \cdot \mathrm{L}^{-1}$ selenate treatment. Plants in the $0.75 \mathrm{mg} \cdot \mathrm{L}^{-1}$ selenate $/ 37 \mathrm{mg} \cdot \mathrm{L}^{-1}$ sulfate treatment had mean sulfate concentrations in their leaf tissue equal to that of plants in the $1.0 \mathrm{mg} \cdot \mathrm{L}^{-1}$ selenate treatment (Fig. 2).

These results are consistent with findings by Charron et al. (2001), Kopsell and Randle (1999), and Kopsell et al. (2000). In other words, in rapid-cycling $B$. oleracea, Se either upregulates or prevents the downregulation of $S$ uptake by the plant's roots. The findings of the current study take this interesting phenomenon a step further. Selenium upregulates $\mathrm{S}$ acquisition such that it equals or exceeds that of plants given elevated S.

A potential way in which the presence of Se within the plant might prevent the downregulation of S uptake is by incorporating it into the protein glutathione. If $\mathrm{Se}$, in the form of selenocysteine, were incorporated into glutathione rather than cysteine, the slight chemical differences of Se from $\mathrm{S}$ could potentially interfere with the protein's proper functioning. A similar influence on $\mathrm{S}$ concentrations as a result of $\mathrm{Se}$ in growing medium is seen in Allium cepa L. plants (Kopsell and Randle, 1997b).

The percent $S$ content of rapid-cycling plants in the control and elevated $\mathrm{S}$ treatment was about equal to the percent $\mathrm{S}$

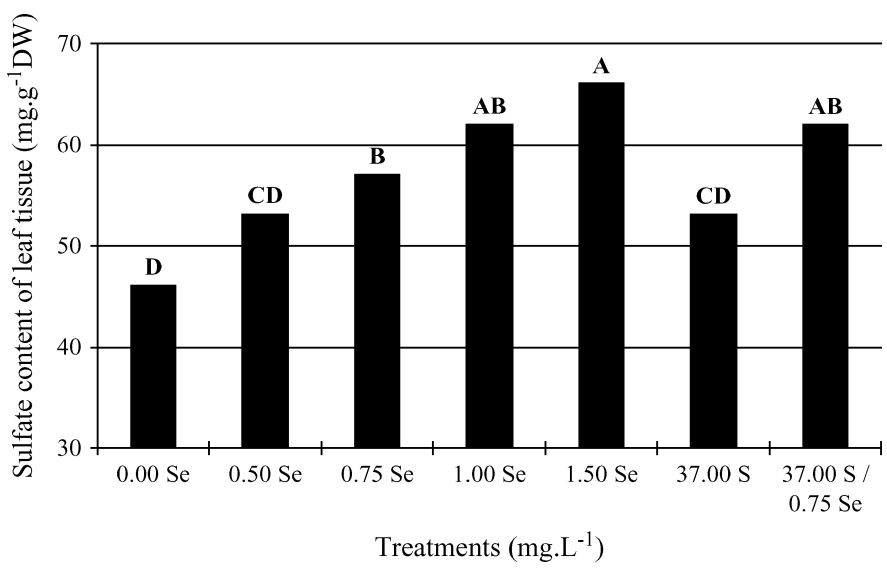

Fig. 2. Sulfate (milligrams per gram dry weight) concentrations in leaf tissue of hydroponically grown rapid-cycling Brassica oleracea at 30 to $31 \mathrm{~d}$. Plants were exposed to Se concentrations ranging from 0 to $1.5 \mathrm{mg} \cdot \mathrm{L}^{-1}$, or an elevated $\mathrm{S}$ of $37 \mathrm{mg} \cdot \mathrm{L}^{-1}$ more than the $96 \mathrm{mg} \cdot \mathrm{L}^{-1}$ sulfate concentration preexisting in the nutrient solution $(P<0.01)$. Letters represent significant mean separations by Fisher's LSD test.

content of various cultivars and cultivars of commercially grown B. oleracea reported by Albrecht et al. (1990) and Gupta and Monro (1969). Although a number of cancer prevention studies have been conducted in which commercially grown cultivars of $B$. oleracea have been enriched with Se (Davis et al., 2002; Stoewsand et al., 1989), S content of those plants was not reported.

\section{Conclusion}

A primary research objective of this project was to determine what Se concentrations in growing media produced $B$. oleracea plants with maximum nutritional value. If maximum nutritional value can be achieved without a significant decrease in plant biomass or glucosinolate production, the potential for a commercial niche crop with optimum levels of human-essential nutrients is feasible.

The increase of $\mathrm{S}$ in the tissue of plants exposed to $\mathrm{Se}$ concentrations in hydroponic growing media, such that their $\mathrm{S}$ content was equal to or exceeded that of plants exposed to elevated sulfate levels in nutrient solution, suggests that Se upregulates, or prevents the downregulation of, $\mathrm{S}$ uptake in $B$. oleracea. Despite higher S concentrations in plants exposed to the selenate treatments, production of five of the seven glucosinolates was lower in Se-exposed plants. The availability of $\mathrm{S}$, and the lack of S-containing glucosinolates, suggest that Se interferes with glucosinolate metabolism. The $0.75 \mathrm{mg} \cdot \mathrm{L}^{-1}$ selenate $/ 37 \mathrm{mg} \cdot \mathrm{L}^{-1}$ sulfate treatment supports this conclusion in the case of glucoiberin, glucoraphanin, and sinigrin.

Although the production of sinigrin, glucoraphanin, and glucobrassicin (three glucosinolates with catabolism products that are inducers of anticarcinogenic phase II enzymes) was decreased by the presence of $\mathrm{Se}$, concentrations of these glucosinolates at the $0.5 \mathrm{mg} \cdot \mathrm{L}^{-1}$ selenate treatment was still relatively high. The $0.5 \mathrm{mg} \cdot \mathrm{L}^{-1}$ selenate treatment that had $\approx 180 \mu \mathrm{g} \cdot \mathrm{g}^{-1}$ Se in leaf tissue, which is close to the $200 \mu \mathrm{g} \cdot \mathrm{g}^{-1}$ daily Se supplement concentration associated with a reduced risk of lung, colon, and prostate cancers. Experiments using economic cultivars of $B$. oleracea fertilized with selenate yielded 
similar Se concentrations in plant tissue (Hamilton and Beath, 1964). It may therefore be possible to produce a crop of $B$. oleracea vegetables that not only have preexisting anticarcinogen-inducing health benefits from glucosinolates, but have the added health benefit of appropriate amounts of Se as well.

\section{Literature cited}

Albrecht, J.A., H.W. Schafer, and E.A. Zottola. 1990. Relationship of total $\mathrm{S}$ to initial and retained ascorbic acid in selected cruciferous and noncruciferous vegetables. J. Food Sci. 55:181-183.

Anderson, J.W. and A.R. Scarf. 1983. Se and plant metabolism, p. 241275. In: D.A. Robb and W.S. Pierpont (eds.). Metals and micronutrients: Uptake and utilization by plants. Academic Press, London.

Brown, P.D. and M.J. Morra. 1997. Control of soil-borne plant pests using glucosinolate-containing plants. Adv. Agron. 61:167-229.

Charron, C.S., D.A. Kopsell, W.M. Randle, and C.E. Sams. 2001. Sodium selenate fertilisation increases Se accumulation and decreases glucosinolate concentration in rapid-cycling Brassica oleracea. J. Sci. Food Agr. 81:962-966.

Charron, C.S., A.M. Saxton, and C.E. Sams. 2005. Relationship of climate and genotype to seasonal variation in the glucosinolate myrosinase system. I. Glucosinolate content in ten cultivars of Brassica oleracea grown in fall and spring seasons. J. Sci. Food Agr. 85:671-681.

Chistensen, B.W., A. Kjaer, J.O. Madsen, E.E. Olsen, O. Olsen, and H. Sørensen. 1982. Mass-spectrometric characteristics of some pertrimethyl-silylated desulphoglucosinolates. Tetrahedron 38:353-357.

Ciska, E., B. Martyniak-Przybyszewska, and H. Kozlowska. 2000. Content of glucosinolates in cruciferous vegetables grown at the same site for two years under different climatic conditions. J. Agr. Food Chem. 48:2862-2867.

Clark, L.C., G.F. Combs, Jr., B.W. Trunbull, E.H. Slate, D.K. Chalker, J. Chow, L.S. Davis, R.A. Glover, G.F. Graham, E.G. Gross, A. Krongrad, J.L. Lesher, Jr., H.K. Park, B.B. Sanders, Jr., C.L. Smith, and J.R. Taylor. 1996. Effects of Se supplementation for cancer prevention in patients with carcinoma of the skin. JAMA. 276: 1957-1963.

Davis, C.D., H. Zeng, and J.W. Finley. 2002. Se-enriched broccoli decreases intestinal tumorigenesis in multiple intestinal neoplasia mice. J. Nutr. 231:307-309.

Fahey, J.W., A.T. Zalcmann, and P. Talalay. 2001. The chemical diversity and distribution of glucosinolates and isothiocyanates among plants. Phytochemistry 56:5-51.

Gross, H.B., T. Dalebout, C.D. Grubb, and S. Abel. 2000. Functional detection of chemopreventive glucosinolates in Arabidopsis thaliana. Plant Sci. 159:265-272.

Gupta, U.C. and D.C. Monro. 1969. Influence of S, molybdenum and phosphorus on chemical composition and yields of brussels sprouts and of molybdenum on $\mathrm{S}$ contents of several plant species grown in the greenhouse. Soil Sci. 107:114-118.

Halkier, B.A. and L. Du. 1997. The biosynthesis of glucosinolates. Trends Plant Sci. 2:425-431.

Hamilton, J.W. and O.A. Beath. 1964. Amount and chemical form of Se in vegetable plants. Agr. Food Chem. 12:371-374.

Hecht, S.S. 2000. Inhibition of carcinogenesis by isothiocyanates. Drug Metab. Rev. 32:395-411.
Ip, C. and H.E. Ganther. 1992. Comparison of Se and S analogs in cancer prevention. Carcinogenesis 13:1167-1170.

Ip, C., C. Hayes, R.M. Budnick, and H.E. Ganther. 1991. Chemical form of Se, critical metabolites, and cancer prevention. Cancer Res. 51:595-600.

Kliebenstein, D.J., J. Kroymann, P. Brown, A. Figuth, D. Pedersen, J. Gershenzon, and T. Mithchell-Olds. 2001. Genetic control of natural variation in Arabidopsis glucosinolate accumulation. Plant Physiol. 126:811-825.

Kopsell, D.A. and W.M. Randle. 1997a. Selenate concentration affects selenium and sulfur uptake and accumulation by 'Granex 33' onions. J. Amer. Soc. Hort. Sci. 122:721-726.

Kopsell, D.A. and W.M. Randle. 1997b. Short-day onion cultivars differ in bulb Se and $\mathrm{S}$ accumulation which can affect bulb pungency. Euphytica 96:385-390.

Kopsell, D.A. and W.M. Randle. 1999. Se accumulation in a rapidcycling Brassica oleracea population responds to increasing sodium selenate concentrations. J. Plant Nutr. 22:927-937.

Kopsell, D.A., W.M. Randle, and H.A. Mills. 2000. Nutrient accumulation in leaf tissue of rapid-cycling Brassica oleracea responds to increasing sodium selenate concentrations. J. Plant Nutr. 23:927935.

Kushad, M.M., A.F. Brown, A.C. Kurilich, J.A. Juvik, B.P. Klein, M.A. Wallig, and E.H. Jeffery. 1999. Variation of glucosinolates in vegetable crops of Brassica oleracea. J. Agr. Food Chem. 47:15411548.

Lauchli, A. 1993. Se in plants: Uptake, functions, and environmental toxicity. Bot. Acta. 106:455-468.

Levander, O.A. 1982. Se: Biochemical actions, interactions, and some human health implications, p. 345-368. In: A.S. Prasad (ed.). Clinical, biochemical, and nutritional aspects of trace elements. Alan R. Liss, New York.

Louda, S. and S. Mole. 1991. Glucosinolates: Chemistry and ecology, p. 123-164. In: G.A. Rosenthal and M.R. Berenbaum (eds.). Herbivores: Their interactions with secondary plant metabolites, 2nd edn. Vol. 1: The chemical participants. Academic Press, New York.

Mailer, R.J. 1989. Effects of applied S on glucosinolate and oil concentrations in the seeds of rape (Brassica napus L.) and turnip rape (Brassica rapa L. var. silvestris (Lam.) Briggs). Austral. J. Agr. Res. 40:617-624.

Randle, W.M., D.E. Kopsell, and D.A. Kopsell. 2002. Sequentially reducing sulfate fertility during onion growth and development affects bulb flavor at harvest. HortScience 31:118-121.

Rosa, E.A.S., R.K. Heaney, and G.R. Fenwick. 1997. Glucosinolates in crop plants. Hort. Rev. (Amer. Soc. Hort. Sci.) 19:99-203.

Stoewsand, G.S., J.L. Anderson, L. Munson, and D.J. Lisk. 1989. Effect of dietary brussels sprouts with increased Se content on mammary carcinogenesis in rat. Cancer Lett. 45:1989.

Toler, H.D. and C.E. Sams. 2001. The effects of Se on the production of glucosinolates known to produce anti-carcinogen inducing metabolites. HortScience 36:556 (abstr.).

U.S. Department of Agriculture. 2003. Dietary reference intakes: Elements. 5 Mar. 2006. <http://warp.nal.usda.gov/fnic/etext/ 000105.html>.

Zhang, Y. and P. Talalay. 1994. Anticarcinogenic activities of organic isothiocyanates: Chemistry and mechanisms. Cancer Res. 54:1976s1981 s. 